\title{
The Effect of Communicative Activities on Libyan Secondary School Students' Speaking Performance in Malaysia
}

\author{
Eman Abdussalam Owen \\ Faculty of Educational Studies, Universiti Putra Malaysia (UPM), Malaysia, \\ emanaowen@yahoo.com
}

\author{
Abu Bakar Razali \\ $\mathrm{PhD}$, Faculty of Educational Studies, Universiti Putra Malaysia (UPM), Malaysia, \\ abmr_bakar@upm.edu.my
}

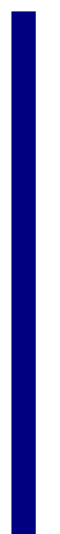

\begin{abstract}
This study was conducted to investigate whether implementing communicative activities, in particular information gap and language games, in Libyan secondary schools affect students' speaking performance. A quasi-experimental, nonequivalent, pre-test-post-test design was conducted on 42 first year Libyan secondary school students in a private Libyan international school in Malaysia. Eight different information gap and language game activities based on communicative language teaching (CLT) principles were implemented for 15-20 minutes during eight sessions. The results from the paired sample t-test indicated that there was a significant difference between the pre-test compared to the posttest. Students' speaking performance improved after implementing the communicative activities in the classroom. However, the results from the independent sample-test illustrate differences in mean scores between male and female students, which are in favour or female students. Nevertheless, the differences between genders were not statistically different.
\end{abstract}

Keywords: Communicative Language Teaching (CLT), communicative activities, speaking performance, information gap, language games

\section{INTRODUCTION}

English language teaching and learning have always been a challenge for ESL/EFL teachers and students alike. ESL/EFL teachers face difficulties while teaching the English language and students face different problems when learning it. Many methods and approaches have appeared to provide ESL/EFL teachers and learners with different ways to reach their goals of teaching and learning through various means. Some methods quickly disappeared while others have been around for a long time. It is fallacy to imply that there is one method suitable for all situations across time, because

Citation: Owen, E. A., \& Razali, A. B. (2018). The Effect of Communicative Activities on Libyan Secondary School Students' Speaking Performance in Malaysia. International Journal of Instruction, 11(4), 45-60. https://doi.org/10.12973/iji.2018.1144a 
students' learning needs evolve, and thus the teaching methods and approaches also have to change accordingly.

Communicative Language Teaching (CLT) approach was introduced through the Libyan English language curriculum of 1999-2000 by the Ministry of Education to improve students' communication skills (Zarrough et al., 2001). Research indicates that there are many factors affecting the implementation of CLT even when teachers have shown interest in the approach (Farooq, 2015; Rahimi \& Naderi, 2014). In the Libyan context, according to Shihiba (2011), teachers generally have shown good attitude towards CLT and its principles and goals. However, teachers in Libya still use the traditional methods rather than the CLT approach in teaching the English language because some teachers still doubt its effectiveness (Orafi, 2008). While Abukhattala (2014) indicates that it is a Western approach and should be further studied to investigate its effectiveness and he also questions whether it a practical approach that can be beneficial in the Libyan context. Although research around the world shows that communicative activities promoted in CLT, such as language games, can motivate learners and help them engage in learning when it is interesting and enjoyable, learners in Libya are deprived from learning through a playful environment (Aldabbus, 2008).

Saghair (2006) believes that in Libya, the activities implemented in the classroom are teacher dominated and the traditional way of teaching is still used in the classroom. This in turn does not help the students to be proficient in speaking the English language. Libyan students lack speaking practice inside and outside the classroom, and as a result face difficulties when communicating with others (Ben Hamid, 2010). In addition, many educationists believe that gender in second language learning may have some effect on the process of language learning and learner's performance (Brown, 2000). Whether the effect is positive or negative, it is debateable according to the existing studies (Motallebzadeh \& Nematizadeh, 2011; Lumley and O'Sullivan, 2005; Chastain, 1988). Gender is a variable which has been shown to play a significant role in the success of learners in the process of language learning (Dörnyei, 2005).

In this study, the speaking skill is the focus of the study because in the Libyan context, research shows that students with an experience of three to four years of instruction of English at secondary schools still have difficulty in daily communication (Shihiba, 2011). Gender is the second focus in the study because male students sometimes avoid learning the English language and afterwards teaching it whereas females in general prefer to learn the English language and do well in the subject and this is due to social reasons (Omar, 2014). Further investigation was required on the role of gender on language learning and particularly the effect of communicative activities on speaking performance in the Libyan context. Hence, there was a necessity to embark on the current study to investigate the gaps in literature.

\section{Research questions}

1. Is there a significant difference between students' speaking performance before and after implementing Communicative activities (i.e., information gap and language games)? 
2. Is there a significant difference between male and female Libyan students' speaking performance (i.e., speaking scores) before and after implementing Communicative activities (i.e., information gap and language games)?

\section{LITERATURE REVIEW}

Some researchers believe that one of the reasons why English as a second language (ESL) students are reluctant to speak English is because of the continued use of the traditional methods inside the classrooms (Esmail, Ahmed, \& Noreen, 2015). While Farooq (2015) and Abebe, et al. (2012) believe that communicative activities are essential when using CLT in the classroom; however, to benefit from them there should be proper facilities and well trained teachers. Watamni and Gholami (2012) conducted a study on elementary students and results from their study show that the use of information gap activities in the classroom improves student's interaction with the teacher and other students and it maximizes students' opportunities to speak. Another study by Efrizal (2012) which engaged in a classroom action research concluded that student motivation and speaking skills improved when using CLT and the use of communicative activities develops communicative competence. Ahmed at al., (2014) conducted a study that included 260 students from 13 schools in Terengganu, Malaysia for six months. They used a mixed method design, and a number of communicative activities that required pair and group work were adopted. Findings indicated positive impact of CLT activities on speaking skills. Meanwhile, Jondeya (2011) conducted a study on elementary female students in Gaza. She used information gap activities (i.e., role play, jigsaw, describe and draw, ask and answer, fill the gap, and puzzles) as a treatment for the experimental group in her study. Her findings showed that students' speaking post-test score in the experimental group were significantly different from the control group. She concluded that information gap activities help maximize students' opportunities to speak, encourage practice in the target language and provide benefits of student-student interaction, and so enhance the oral proficiency of the students.

In the Libyan English classrooms the traditional methods are still used and this is one of the reasons that Libyan students are not capable of speaking and have difficulties in learning the English language even after many years of studying it (Ben Hamid, 2010). The traditional methods, such as the Grammar translation method (GTM), have been used for so long that Libyan teachers found difficulty in changing how language was taught in the classroom even though the current curriculum is based on the more modern Communicative Language Teaching (CLT) approach. Due to the continuous focus on using the traditional approach in teaching English, this may limit the benefits from implementing the CLT approach (Altaieb, 2013; Orafi \& Borg, 2009).

The different approaches that existed in the Libyan English education scene focused on certain aspects of learning the English language. For example, some aimed for accuracy, others for fluency, while another aimed for interaction and communication (Orafi, 2008). Grammar Translation Method (GTM) that is based on drilling memorization and translation might suit some students more than others. Likewise approaches that focus on interaction and communication, such as CLT approach, may be suitable for some students more than others such as according to gender type or age. The role of gender in 
language teaching has been a controversial topic. Some research has come up with conclusion that there is a significant difference between male and female learners in language performance. For example, Demie (2000) and Motallebzadeh \& Nematizadeh, (2011) highlighted that there was a significant difference between male and female students in language performance in favour of females. This was not in conformance with the studies done by Chastain (1988) (as cited in Motallebzadeh \& Nematizadeh, 2011) which indicated males significantly performed better than females in oral skills. Moreover, Bindin and Jusoff (2009) supported the results by stating that there is a significant difference between language performance of male and female students. In support of both ideas, Stumpf and Stanely (1998) discussed that women perform better than men in a range of language skills, while male learners outperform female learners in other subjects. Meanwhile researchers such as Lumley and O'Sullivan (2005) indicated that even though females perform better than males but it is not significantly different.

It is apparent from all the previous studies that there is still no conclusive results about significant differences between male and female speaking performance. Taken this issue into account the current study wanted to investigate further whether males' and females' speaking performance differ after taking part in the communicative activities based on CLT approach. The results may be helpful in understanding the activities that students benefit best and thus may provide teachers with valuable information that improves language learning and teaching.

\section{Communicative Language Teaching (CLT) Approach}

Communicative language teaching (CLT) is an approach that aims to develop communicative competence, which is a notion coined by Hymes (1971) and includes knowledge of grammatical, discourse, sociolinguistic and strategic competence (Canale, 1983). Richards and Rogers (2001) explain that in CLT, students learn the language through using it to communicate and the activities used in the classroom should be authentic and meaningful, and communication can happen through trial and error. In CLT approach grammar rules are discovered rather than taught directly and all language skills should be linked together in teaching since in the real world they do not occur separately (Richards, 2005).

CLT approach was introduced in Libya through a series of English language books by Garnet Publishing and the goal was to develop students' skills to be able to interact and communicate in the English language but problems hindered learners from benefiting from this approach (Orafi, 2015). One of these problems is the mismatch between the curriculum and the nature of examinations in Libya, and therefore the difficulty to fulfil the principles and fundamentals of CLT (Orafi \& Borg, 2009). The curriculum based on CLT was challenging for teachers because it was assigned without neither prior notice nor arrangements, and it caused problems such as difficulties in implementing speaking activities, unmotivated teachers and students, and in some cases this approach was rejected by some teachers (Orafi, 2015). Moreover any curriculum that implements a new approach requires qualified teachers and proper materials, motivated students, small classes among other things, to be able to achieve its goal (Altaieb, 2013). 


\section{Communicative Activities}

In CLT approach, there can be various numbers of communicative-based activities that help achieve the goal of the communicative approach (Richards, 2005). Communicative activities were divided by Littlewood (1981) into 'functional and social activities'. Functional activities are used when teachers require learners to use the language to get the meaning across as effectively as possible and it requires the use of language resources to overcome an information gap or solve a problem, such as information gap or jigsaw activities. While social interaction activities is associating language to specific social contexts, e.g., role-play, information-transfer, puzzles and game activities, etc. The rationale for choosing information gap and language game communicative activities in the current study was to focus on both functional and social activities and study their effects on Libyan students' speaking performance.

\section{Information Gap}

Information gap activities is when students interact with each other to share unfamiliar knowledge because the purpose of communication is to close a gap of information between students interacting (Goh \& Burns, 2012). Richards (2006) explains that the notion of information gap is an important aspect of communication in CLT. Examples of this type of activity is pictures with differences, or ordering information to reach to new information. By using information gap activities that are based on real-life situations through pair and group work, students become more motivated and confident towards learning (Ismaili \& Baijrami, 2016). Moreover, Utomo (2016) added that by using information gap activities, students are provided with opportunities to practice the speaking skill and they can motivate them towards learning the English language. This indicates that information gap activities can improve comprehension of spoken language as well as increase student's vocabulary.

\section{Language Games}

Language games refer to the physical and mental activities that require participation and communication from the students to accomplish a language learning goal, and it has been defined by Hadfield (1990, p. 5) as an "activity with rules, a goal, and an element of fun." Hadfield adds that they can be either co-operative games where players (in this case students) work together to reach the goal or competitive games where the players try to be the first to reach the goal. Examples of language games are guessing games, describing and drawing, and board games; and they can be either co-operative or competitive depending on whether it's implemented in groups or pairs and the goal of the activity. Language games can encourage students to participate and simulate real-life situations and have fun at the same time (Langran \& Purcell, 1994). Even if some teachers do not have a high positive attitude towards using language games, they still believe students' language can improve through a playful environment that requires interaction and communication (Al-Bulushi and Al-Issa, 2017). These type of activities can be used for learners at all levels and can be effective for learning all four skills. Speaking opportunities can be produced by creating a playful context where learners can practice the target language interactively in a friendly environment without any pressure 
(Aldabbus, 2008). The use of communicative activities in the type of language games can help and motivate learners to use the target language and share information by interaction with others in a meaningful context and therefore maximize language educational effect. (Wang 2010; Dewi et al., 2016).

\section{Theoretical Underpinning}

Sociocultural theory by Vygotsky (1978) gives importance to social interaction and emphasizes the role of language, communication and instruction to obtain and develop knowledge. Vygotsky considers talk as the main means of the process of learning because through it is possible to identify what the speaker knows and understands. The theory shows that interaction with others surrounding the learner such as teachers or peers in the classroom, can help them learn more than when they are by themselves. Learning is developed through what Vygotsky calls the 'Zone of Proximal development' (ZPD), where the learner is helped through interaction or guidance of the surrounding people and as a result their mental development level can be raised. The learner goes through four levels to transit from other regulation to self-regulation and this strategy is called 'Scaffolding'.

According to Vygotsky (1978) learners can learn a language by the help of the surrounding environment and through interaction with peers. The sociocultural theory suggests learning happens when learners or students participate to gain new information. The role of a learner here is to be an active member of the group and work together to participate in solving the tasks or problems. The teacher, on the other hand, is a facilitator that helps his students get the knowledge required. Learners gain knowledge about the target language through interaction with one another. Through scaffolding, the learners shifts from being dependent to independent learners that solve problems or perform the required tasks or activity. Sociocultural theory supports the principles of CLT, as Vygotsky (1978) shows that this theory proposes importance to social interaction and emphasis the role of language, communication and instruction to gain knowledge.

\section{METHOD}

The study employed a quasi-experimental design (non-randomized control group). This design is not considered a true experiment because it lacks random sampling. Creswell (2009) claims that using quasi-experiment method in an intact classroom provides the best solution for studies where random sampling cannot be applied. In this type of design usually two or more experimental and control groups are created, and a series of interventions are employed. In this study two first year secondary classrooms from a Libyan school in Malaysia participated in the current study, one served as the experimental group, while the other as the control group.

\section{Research Participants}

This study was conducted in the first semester of 2016/2017 for eight sessions at a Libyan international public school in Malaysia. The two groups of students who were the sample in the experimental and control groups were two classrooms of first year 
secondary students. A total number of 42 students took part in the study, 20 for the experimental group and 22 for the control group. Students were randomly assigned to the groups, 18 students were 15 years old and 24 were 16 years old. The total number of males were 19 while the females were 23 . Table 1 shows the demographic information of the respondents.

Table 1

Background of respondents $(\mathrm{N}=42)$

\begin{tabular}{llllll}
\hline Variable & & Frequency & Percentage & Min. & Max. \\
\hline Gender & Male & 19 & 45.2 & & \\
& Female & 23 & 54.8 & & \\
Age & 15 years old & 18 & 42.9 & 15 & 16 \\
& 16 years old & 24 & 57.1 & & \\
Group & Experimental & 20 & 47.6 & & \\
& Control & 22 & 57.1 & & \\
\hline
\end{tabular}

\section{Research Instruments and Data Collection}

\section{Research Instruments}

The current study used an oral speaking test to evaluate students' level in the spoken language and then the experimental group was exposed to the treatment (i.e., implementation of information gap and language game activities). After that, both groups were given another speaking test to examine whether their scores have changed due to the exposure of the treatment. These tests serve as the pre- and post-tests for the study. The tests consisted of five main open-ended questions that included everyday topics that previously covered by the class teacher during earlier sessions. These tests comprise of general questions about everyday life, e.g., family, school, friends, social media, etc. The scoring of the oral speaking test was adapted from Harris's testing scale model (1972) to measure oral performance based on five major criteria: fluency, vocabulary, grammar, comprehension, and pronunciation with some modifications. Therefore, the total score was sub-dived into five sections according to the five criteria of Harris's scale model. The treatment or the communicative activities that were used in the current study were two types. Information gap activities that included picture with different information, ordering pictures, directed dialogue and a strip of pictures or sentences that were used in pair and group works. While the language game activities were guessing game, describing and drawing, instruction board games and passing on information which were also used in pair and group works.

\section{Data Collection}

Prior to data collection, permission letters were obtained from the school administration office and permission was also taken from the students' parents to conduct the study. The data was collected through an oral speaking test, which served as the pre-test. The oral speaking test consists of five main questions that required from 5-7 minutes. The class teacher called each student out of their classroom during the last sessions of their school day. The test took place in a separate room where students were asked five questions. The purpose for choosing the last sessions is that students may not return to 
class after the test and talk to their classmates about the questions of the test. After that, eight different communicative activities were implemented for the experimental group. Finally, another set of data was collected through the second speaking test, which served as the post-test. Both tests were the same but in different order.

\section{FINDINGS}

Prior to the presentation of inferential analysis, namely findings from analyses of independent sample t-test and paired sample t-test, the data was examined for normality and reliability assumptions. After data entry, the missing data and outliers were checked.

\section{Exploratory Data Analysis (EDA)}

Normality test, mean, modes and medians were calculated to show if the data is normally distributed. The reliability of data was also checked by using Cronbach's alpha.

\section{Normality Test}

Based on the normality test the results show that, the distribution of the pre-test data is normally distributed based on Shapiro-Wilk Statistics $(p>.05)=0.440$. With regards to normality distribution of the post-test, the results show it is also normally distributed (p $=0.380)$. The Skewness and Kurtosis value indicated that the data are normally distributed, the values were all found to be between \pm 1 and \pm 2 , which are accepted according to George \& Mallery (2003).

Table 2

Test of Normality

Tests of Normality

\begin{tabular}{lllllll}
\hline & \multicolumn{7}{l}{ Kolmogorov-Smirnov ${ }^{\mathrm{a}}$} & \multicolumn{3}{l}{ Shapiro-Wilk } \\
& Statistic & Df & Sig. & Statistic & df & Sig. \\
\hline Pretest & .089 & 42 & $.200^{*}$ & .974 & 42 & .440 \\
Posttest & .078 & 42 & $.200^{*}$ & .972 & 42 & .380 \\
\hline
\end{tabular}

The means, modes, and medians of the data for both the pre-test and post-test were computed in order to validate the normality distribution of the data. Table 3 displays the outcome of the means, medians and modes as part of the exploratory data analysis (EDA).

Table 3

Mean, modes and medians of the Pre -Test and the Post-Test

\begin{tabular}{llll}
\hline Test & & & \\
\hline & & Pre-test & Post-test \\
\hline $\mathrm{N}$ & Valid & 42 & 42 \\
& Missing & 0 & 0 \\
Mean & & 14.1 & 15.62 \\
Median & 14.5 & 16 \\
Mode & 15 & 16 \\
\hline
\end{tabular}




\section{Reliability}

Cronbach's alpha was also used to determine the internal consistency of the data of pre and post- test and the five criteria and the speaking test to ensure the reliability of the data. The Cronbach's alpha for the items $a=0.917$, which is acceptable value as it is greater than 0.7 which is considered reliable (George \& Mallery, 2003). The assumption of normality is not violated for either group of scores.

\section{Inferential Analysis}

A paired sample T- test was conducted to compare the difference in speaking scores between the experimental and the control groups in the pre-test and the post-test. The null hypothesis used to answer the research question is:

Ho1: There is no significant difference between students' pre-test and post-test speaking scores after the implementation of the communicative activities.

The results in table 4 below indicate that, there is a significant difference between the pre-test and the post tests. On average, the students performed better in the posttest $(M=$ $15.62, S D=5.41)$ as compared with the pretest $(M=14.10, S D=5.07)$. Based on the results of paired samples t-test, $t(41)=-5.714, p=.000,95 \%$ CI [-2.062, -.985], since the significant value was smaller than alpha, the null hypothesis was rejected. It can be concluded that the treatment had a significant effect on students' speaking performance.

Table 4

Paired sample T-Test between Pre - Test and Post - Test

\begin{tabular}{|c|c|c|c|c|c|c|c|c|c|}
\hline \multicolumn{10}{|c|}{ Paired Samples Test } \\
\hline & & \multicolumn{5}{|c|}{ Paired Differences } & \multirow[t]{5}{*}{$\overline{\mathrm{T}}$} & \multirow[t]{5}{*}{$d f$} & \multirow{5}{*}{$\begin{array}{l}\text { Sig.(2- } \\
\text { tailed) }\end{array}$} \\
\hline & & \multirow[t]{4}{*}{$\mathrm{M}$} & \multirow[t]{4}{*}{ SD } & \multirow{4}{*}{$\begin{array}{l}\text { Std. } \\
\text { Error } \\
\text { Mean }\end{array}$} & \multirow{3}{*}{\multicolumn{2}{|c|}{$\begin{array}{l}95 \% \text { Confidence } \\
\text { Interval of the } \\
\text { Difference }\end{array}$}} & & & \\
\hline & & & & & & & & & \\
\hline & & & & & & & & & \\
\hline & & & & & $\mathrm{L}$ & $\mathrm{U}$ & & & \\
\hline \multirow[t]{2}{*}{ Pair } & Pretest - & - & 1.728 & .267 & - & - & - & 41 & .000 \\
\hline & Posttest & 1.524 & & & 2.062 & .985 & 5.714 & & \\
\hline
\end{tabular}

The estimated marginal mean of the pre-test five criteria namely (fluency1, vocabulary1, comprehension1, grammar1 and pronunciation1) and post -test (fluency2, vocabulary2, comprehension2, grammar2 and pronunciation2) is presented in figure 1. The results show that the marginal mean of post -test is higher that of pre-test among the two groups. Figure 1 indicates significant increase of student's sub-speaking scores graphically. The vocabulary mean scores for the experimental group in the pre-test $(M=$ $3.10, S D=1.026)$ and the control group $(M=3.00, S D=1.059)$. While the mean score for the experimental group in the post-test $(M=4.25, S D=.910)$ and the control group $(M=3.23, S D=1.193)$. It is clear that students' vocabulary improved the most, the magnitude differences in the means (mean differences $=.714,95 \%$ CI: -.956 to -.473 ). 


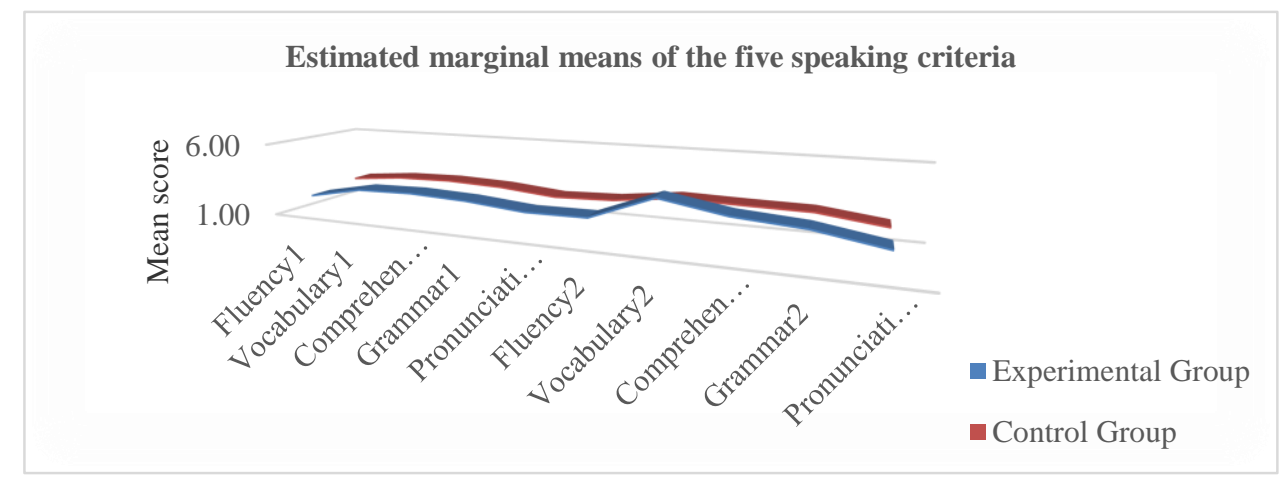

Figure 1

Estimated marginal means of speaking criteria for pre-test and post-test

The estimated marginal mean of the pre-test and post -test in figure 2 shows that the marginal mean of post-test for the experiment group $M=16.35$, is higher that of the control group $M=14.95$, compared to the mean scores in the Experimental group pretest, $M=13.90$ and the control group $M=14.27$ among the two groups.

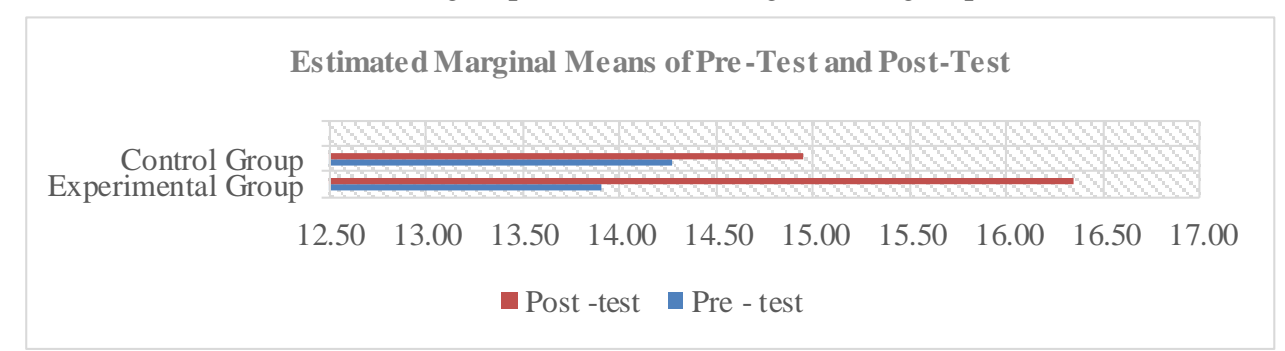

Figure 2

Estimated marginal means of total speaking scores

An independent sample T- test was performed to compare the speaking test result scores for both males and females. The null hypothesis that was formed to answer the research question:

Ho2: There is no significant difference between males and female students' speaking scores before and after implementing the communicative activities.

The results given in table 5 show that there is no statistical difference in scores in gender; for males, before the treatment (implementation of the communicative activities) $(\mathrm{M}=13.16, \mathrm{SD}=5.39)$ and after the treatment (implementation of the communicative activities) $(\mathrm{M}=14.42, \mathrm{SD}=5.78)$. For female students results are given for before the treatment $(M=14.87, S D=4.76)$ and after the treatment $(M=16.61, S D=4.99)$. The results are shown for the pre-test, t-test $(\mathrm{t}(40)=1.093, P=0.281)$ and the post-test $(\mathrm{t}(40)=$ 1.316, $P=0.196)$. The magnitude differences in the means are found in favour of females (mean differences in the pre-test $=-1.712,95 \%$ CI: -4.877 to 1.454 ) and (mean 
differences in the post-test $=-2.188,95 \% C I:-5.547$ to 1.172 ). Overall, female students scored higher than male but since the significant value was greater than alpha at .05 level of significance, the authors fail to reject the null hypotheses.

Table 5

Independent sample t-test of Pre-test and Post-test Differences between Male and Female on Speaking Test

\begin{tabular}{|c|c|c|c|c|c|c|}
\hline & & Mean & SD & $d f$ & $t$ & $P$ \\
\hline \multirow[t]{2}{*}{ Pretest } & Male & 13.16 & 5.39 & \multirow[t]{2}{*}{-1.712} & \multirow[t]{2}{*}{40} & \multirow[t]{2}{*}{.281} \\
\hline & Female & 14.87 & 4.76 & & & \\
\hline \multirow[t]{2}{*}{ Posttest } & Male & 14.42 & 5.78 & \multirow[t]{2}{*}{-2.188} & \multirow[t]{2}{*}{40} & \multirow[t]{2}{*}{.196} \\
\hline & Female & 16.61 & 4.99 & & & \\
\hline
\end{tabular}

\section{DISCUSSION}

EFL Libyan students face a number of difficulties in learning the English language, and this may be due to the limited opportunity to practice the language inside and outside the classroom (Ben Hamid, 2010). The communicative activities in this study provide learners with the practice needed to develop their language skills. Through communication and interaction with peers and teachers, students practice and learn the language. According to Richards (2005), there can be an unlimited number of communicative activities; however, the teacher is responsible to consider the context and the different abilities of their students before choosing the appropriate activities.

The first objective and purpose of this study was to investigate whether communicative activities, i.e., information gap and language games, help improve Libyan secondary school students' communicative competence, particularly on their speaking performance. The study reveals that after implementation of the different communicative activities, students' oral speaking performance increased. The type of activities used for this study can allow students experience using the language for real communication. Teaching the speaking skill by using communicative activities while focusing on student-centered learning and working in pairs and groups, through interaction and communication, language learning can occur. The results displayed unlike the control group, the experimental group's mean scores of the post-test increased as compared to their mean scores in the pre-test results. The results are consistent with findings of Nanthaboot (2012) which found that by using communicative activities such as information gap among other types of language games students' English speaking ability increased significantly. The results are also consistent with findings from (Dewi et al, 2016; Efrizal, 2012, Jondeya, 2011). It is important to highlight that when looking at the five criteria separately, learners' vocabulary increased more than other four criteria (i.e., fluency, grammar, comprehension and pronunciation). The fact that after implementing communicative activities students' vocabulary developed the most may be due to the nature of the activities that require use of diverse terminology in order to accomplish the task. The findings support previous research conducted by Utomo's (2016) which revealed that students' vocabulary increases significantly when information gap activities were used in the classroom. Therefore, the communicative activities encouraged language practice, which lead to developing speaking performance. 
The second objective of the current study is to understand whether there is a significant difference between male and female scores after implementing communicative activities based on CLT. The results indicate that although female students scored higher than male learners in the post-test, it was not significantly different. Therefore, the implementation of information gap and language game communicative activities in the Libyan secondary classroom does not have an effect on genders' speaking performance. These results can be due to female students' using more communicative social strategies than male students and therefore used the language more as research suggested by (Kaivanpanah et al., 2012). These findings corroborate the ideas of Motallebzadeh \& Nematizadeh, (2011) and Lumley \& O'Sullivan (2005) who suggested that even though female scores are higher than male score, they are not significantly different. Aloreibi and Carey (2017) discussed that culture plays a role in learning for both genders in particular females that do not prefer to interact in a mixed class. Aloreibi and Carey added in order to carry out an activity in the Libyan classroom sometimes teachers need to separate the students to encourage them to interact and communicate in the target language. Therefore, it is recommended that future research compares and highlights the role of gender on different activities based on CLT principles and how they may enhance language learning while keeping in mind factors such as preference, culture, setting, .etc.

All in all, the authors believe that CLT is an approach that should be implemented widely because it establishes an interactive learning environment that provides learners with opportunities to use the language and research shows that teaching is mostly effective when learners are actively involved in the learning process (Ahmad et al., 2014). The use of communicative activities may be more efficient than the traditional methods of teaching the speaking skills to learners of English (Ismaili \& Bajrami, 2016; Asrobi, Seken \& Suarnajaya, 2013). As for the importance of CLT activities in relation to male/ female students' speaking performance, and since limited research has tackled this issue, further research should be conducted. The research did not reach conclusive finding in regards to differences between genders, it may be due to the fact that the treatment (implementation of communicative activities) was for a short time or the researcher did not take into consideration other factors such as culture and student preferences. Hence, the current study was done on a small sample and for a limited time, it is recommended that research is done on a wider scale and more in depth within the context of Libya, such as a mixed method research, in order to make the findings more generalizable and profound. Furthermore, it is advised not only to investigate effectiveness of communicative activities on language skills, rather compare between the different activities in order to examine which activities can be more efficient in learning the target language.

\section{REFERENCES}

Abebe, T. T.; Davidson, L. M.; \& Biru, F. (2012). The role of instructors in implementing communicative language teaching methodology. Research on Humanities and Social Sciences, 2(3), 52-63. 
Abu Khattala, I. (2014). Introducing the communicative approach in Libya: Resistance and conflict. Faculty of Arts Journal, 4(8).

Ahmad, N. M.; Mansor, N.; Ibrahim, Suria; Salam, W. ; Mama, M.; \&Jamaluddin, H. (2014). The impact of Communicative Approach on Students' Speaking Skills. Journal of Business and Social Development, 2(1), 63-67.

Al-Bulushi, A. H. \& Al-Issa, A. S. (2017). Playing with the Language: Investigating the Role of Communicative Games in an Arab Language Teaching System. International Journal of Instruction, 10(2), 179-198. http://www.e-iji.net/dosyalar/iji_2017_2_12.pdf

Aldabbus, S. (2008). An investigation into the impact of language games on classroom interaction and pupil learning in Libyan EFL primary classrooms (Doctoral dissertation). Newcastle University.

Altaieb, S. (2013). Teachers' Perception of the English language Curriculum in Libyan Public Schools: An investigation and assessment of implementation process of English curriculum in Libyan public high schools. University of Denver.

Aloreibi, A., \& Carey, M. D. (2017). English language teaching in Libya after Gaddafi. In English Language Education Policy in the Middle East and North Africa (pp. 93114). Springer, Cham.

Asrobi, M.; Seken, k.; \& Suarnajaya, w. (2013). the effect of information gap technique and achievement motivation toward students'speaking ability (An Experimental Study of the Tenth Grade Students of Man Selong). Jurnal Pendidikan Bahasa Inggris, 1.

Ben Hamid, N. S. (2010). Developing the Oral skills through vocabulary: A Case Study of Some Secondary School Students in Tripoli. (MA), Academy of Higher Studies, Ganzoor, Libya.

Bidin, S., \& Jusoff, K. (2009). The Influence of Gender and Social Economic Status on Boarding School Students' English Language Performance/L'influence De Sexe Et De La Situation Socio-Économique Sur La Performance En Anglais Chez Les Élèves En Pension. Canadian Social Science, 5(5), 41.

Brown, D. (2000). Principles of language learning and teaching (3rd ed.). New York: Pearson Education.

Canale, M. (1983). From communicative competence to communicative language pedagogy. Language and communication, 1, 1-47.

Creswell, J. W. (2009). Research design: Qualitative and mixed methods approaches. London and Thousand Oaks: Sage Publications.

Demie, F. (2001). Ethnic and gender differences in educational achievement and implications for school improvement strategies. Educational Research, February, 43(1), $91-106$. 
Dewi, R. S.; Kultsum, U.; \& Armadi, A. (2016). Using Communicative Games in Improving Students' Speaking Skills. English Language Teaching, 10(1), 63.

Dörnyei, Z. (2005). The psychology of the language learner: Individual differences in second language acquisition. New Jersey: Lawrence Erlbaum Associates.

Efrizal, D. (2012). Improving Students' Speaking through Communicative Language Teaching Method at Mts Ja-alhaq, Sentot Ali Basa Islamic Boarding School of Bengkulu, Indonesia. International Journal of Humanities and Social Science, 2(20), 127-134.

Esmail, A.; Ahmed, A.; \& Noreen, S. (2015). Why do Pakistani Students are Reluctant to Speak English. Academic Research International, 6 (3).

Farooq, M. U. (2015). Creating a Communicative Language Teaching Environment for Improving Students' Communicative Competence at EFL/EAP University Level. International Education Studies, 8(4), 179.

George, D., \& Mallery, P. (2003). SPSS for Windows step by step: A simple guide and reference. 11.0 update (4th ed.). Boston: Allyn \& Bacon.

Goh, C. C., \& Burns, A. (2012). Teaching Speaking: A Holistic Approach London: Cambridge University Press.

Hadfield, J. (1990). An Collection of Games and Activities for Low to Mid-Intermediate students of English. Intermediate Communication Games . Hong Kong: Thomus and Nelson and Nelson and Sons Ltd.

Ismaili, M., \& Bajrami, L. (2016). Information Gap Activities to Enhance Speaking Skills of Elementary Level Students. Procedia-Social and Behavioral Sciences, 232, 612-616.

Jondeya, R. S. (2011). The Effectiveness of Using Information Gap on Developing Speaking Skills for the Eighth Graders in Gaza Governorate Schools. (Unpublished Dissertation). Gaza: Al-Azhar University.

Kaivanpanah, S.; Yamouty, P.; \& Karami, H. (2012) Examining the Effects of Proficiency, Gender, and Task Type on the Use of Communication Strategies. Porta Linguarum, 17 70-93 Kasper, G. and Kellerman, E. (Eds.). (1997). Communication Strategies: Psycholinguistic and Sociolinguistic Perspectives. Harton, UK: Longman

Langran, J., \& Purcell, S. (1994). Language Games and Activities. Netword 2: Teaching Languages to Adults: ERIC.

Lumley, T., \& O'Sullivan, B. (2005). The effect of test-taker gender, audience and topic on task performance in tape-mediated assessment of speaking. Language Testing, 22(4), 415-437. http://dx.doi.org/10.1191/02655322051t303oa

Motallebzadeh, K. \& Nematizadeh, S. (2011). Does Gender Play a Role in the Assessment of Oral Proficiency?. English Language Teaching, 4(4), 165. 
Nanthaboot, Pranne.(2012) Using communicative activities to develop English speaking ability of Matthayomsuksa three students. (MA.).Srinakharinwirot University, Bangkok.

Omar, Y. Z. (2014). Perceptions of selected Libyan English as a foreign language teachers regarding teaching of English in Libya (Doctoral dissertation, University of Missouri-Columbia).

Orafi, S. M. (2008). Investigating Teacher's Practice and Beliefs in Relation to Curriculum Innovation in English Language Teaching in Libya. The University of Leeds.

Orafi, S. M. S. (2015). Investigating Teachers' Classroom Practices: A Framework to Enhance the Quality of English Language Teaching in Libyan Secondary Schools. Journal of Science and Humanities. ISSN : 2312 - 4962, from http://www.artsc.uob.edu.ly.

Orafi, S. M. \& Borg, S. (2009). Intentions and realities in implementing communicative curriculum reform. System, 37(2), 243-253.

Rahimi, M. \& Naderi, F. (2014). The relationship between EFL teachers' attitudes towards CLT and perceived difficulties of implementing CLT in language classes. International Journal of Applied Linguistics and English Literature, 3(3), 237-245.

Richards, J. C. (2005). Communicative language teaching today: SEAMEO Regional Language Centre.

Richards, J. C. (2006). Developing classroom speaking activities: From theory to practice. Guidelines-Singapore-Periodical For Classroom Language Teachers Then Magazine For Language Teachers-, 28(2), 3.

Richards, J. \& Rodgers, T. (2001). Approaches and methods in language teaching (second ed.). USA: Cambridge University Press.

Saghair, M. A. (2006). The teaching of the speaking skill and the difficulties encountered by secondary school students in Misurata. (MA), Academy of higher studies, Ganzoor, Tripoli.

Shihiba, S. E. S. (2011) An Investigation of Libyan EFL Teachers' Conceptions of the Communicative Learner-Centred Approach in Relation to their Implementation of an English Language Curriculum Innovation in Secondary Schools. (PhD Thesis in Education). University of Durham, UK.

Stumpf, H. \& Stanley, J. C. (1998). Stability and change in gender-related differences on the college board advanced placement and achievement tests. Current Directions in Psychological Science, 7(6), 192-196.

Utomo, W. (2016). Improving Students' Speaking Skills through Information Gap Activities In XI Mia 3 of SMA Muhammadiyah 2 Yogyakarta in Academic Year of 2015/2016. English Language Teaching Journal, 5(7). 
Vygotsky, L. (1978). Interaction between learning and development. Readings on the development of children, 23(3), 34-41.

Wang, Y. H. (2010). Using Communicative Language Games in Teaching and Learning English in Taiwanese Primary Schools. Journal of Engineering Technology and Education,7(1), 126-142.

Watamni, K. \& Gholami, J. (2012). The effect of implementing information-gap tasks on EFL learners' speaking ability. Mjal, 4(4), 267-283.

Zarrough, A. M.; El-Hawat, A.; Al-Abid, A.; Al-Tagouri, A.; Masoudi, A.; Mahmmod, D. \& Ghiblawi, S. (2001). The Libyan national commission for education, culture and science. The development of education in the great Jamahiriya. (National Report). Geneva. 